„Analecta Cracoviensia” 51 (2019), s. 257-281

DOI: http://dx.doi.org/10.15633/acr.3644

Anna Ślósarz

ORCID: 0000-0001-5524-3227

Uniwersytet Pedagogiczny im. Komisji Edukacji Narodowej w Krakowie

\title{
Dwa bieguny katolickiej pedagogiki. Ks. dr hab. Jan Ślósarz i Jacek Woroniecki op
}

Nurty pedagogiki jako nauki społecznej odzwierciedlają sytuację kulturową, a nawet kierunki europejskiej polityki ${ }^{1}$. Mimo że w podręcznikach akademickich wymieniana jest pedagogika religii ${ }^{2}$, a nie pedagogika katolicka, to jednak istnieje i funkcjonuje tradycja katolickiego wychowania - doktryna wychowawcza Kościoła i pedagogia katolicka wpisana w publikacje Jana Pawła II $^{3}$, szkoły prowadzone przez zakony, ruch oazowy, Światowe Dni Młodzieży, Spotkania Młodych w Lednicy, Przystanek Jezus, misje itp.

Podejmowane działania wychowawcze oparte są w nich na katolickiej teologii i antropologii, lecz praktyczne realizacje uzależnione były i są od środowiska, charakterystyki i doświadczeń psychospołecznych nauczycieli oraz wychowanków, przyjętych metod wychowawczych itd. Wśród tych metod jeden biegun stanowią te, które są oparte na autorytecie wychowawcy i przekazywaniu tradycyjnych znaczeń, a drugi te, które stawiają na dialog z wychowankiem, umacnianie jego podmiotowości i tożsamości. Te dwa bieguny odnaleźć można w pismach ks. dr. hab. Jana Ślósarza (1850-1917) oraz Sługi Bożego o. Jacka Woronieckiego op (1878-1949).

1 Por. J. Kostkiewicz, O potrzebie pedagogiki katolickiej jako kierunku [specjalności] edukacji uniwersyteckiej, „Pedagogika Katolicka” 2007 nr 1, s. 29.

2 Por. np. Pedagogika. Podręcznik akademicki, t. 1, red. Z. Kwieciński, B. Śliwerski, Warszawa 2008, s. 261-277.

3 Por. J. Kostkiewicz, O potrzebie pedagogiki katolickiej..., dz. cyt., s. 31. 


\section{Cel i sposób analizy}

Przystępując do porównania źródeł koncepcji katolickiej pedagogiki w ujęciu ks. Ślósarza i o. Woronieckiego op, porównano ich genealogie i koleje życia, odwołując się na gruncie socjologii interpretatywnej do elementów metody biograficznej ${ }^{4} \mathrm{w}$ rozumieniu Jana Lutyńskiego ${ }^{5}$. Zebrano zatem informacje o działalności ks. Ślósarza oraz o. Woronieckiego, tworząc ich biografie tematyczne ${ }^{6}$, czyli w tym wypadku dotyczące kontekstów związanych z formułowaniem zasad pedagogicznych i ich realizacją. Ujawniono w ten sposób zbliżone cechy ich osobowości, procesy zachodzące w otoczeniu społecznym, politycznym i kulturowym, dla którego sformułowali swe wskazania, a także przyczyny różnic ich koncepcji wychowawczych.

Dla uzyskania triangulacji badań, czyli wielostronnego oglądu przyczyn podobieństw i różnic między ujęciami katolickiej pedagogiki przez o. Woronieckiego i ks. Ślósarza, przeprowadzono ponadto analizę ikonograficzną ich portretów z różnych okresów życia.

\section{Analogie i kontrasty w biografiach}

Biografia ilustruje społeczne i historyczne uwarunkowania stosunku człowieka do kulturowych norm, a także sposoby realizacji ideałów w praktyce oraz radzenia sobie z życiowymi trudnościami, toteż

rekonstrukcja przebiegu życia może być zadaniem naukowym, stanowiącym wartościowy materiał badawczy służący do badania różnorodnych zjawisk społecznych?

\section{a) Otoczenie kulturowo-polityczne}

Ksiądz Ślósarz urodził się w zaborze austriackim. Zmarł, gdy od trzech lat trwała rzeź w okopach I wojny światowej, po ludobójstwie na Ormianach

4 Por. Metoda biograficzna w socjologii. Antologia tekstów, red. K. Kaźmierska, Kraków 2012, passim.

5 J. Lutyński, Metoda biograficzna i sposoby otrzymywania materiałów w badaniach socjologicznych, w: Metoda biograficzna w socjologii, red. J. Włodarek, M. Ziółkowski, Warszawa-Poznań 199o, s. 84.

6 S. Juszczyk, Badania jakościowe w naukach społecznych. Szkice metodologiczne, Katowice 2013, s. 130.

S. Juszczyk, Badania jakościowe w naukach społecznych..., dz. cyt., s. 129. 
i przed wybuchem rewolucji październikowej, której dojrzewanie obserwował we Lwowie. Katolicyzm był zagrożony. Natomiast o. Woroniecki obserwował w młodości moralny upadek swego ojca i rodu, potem rewolucję październikową, I i II wojnę światową wraz z następstwami w postaci zimnej wojny i komunistycznego ustroju. Obaj pracowali m.in. we Lwowie, czyli w Rosji, w czasach dochodzącego do władzy bolszewizmu (ks. Ślósarz), ateistycznego komunizmu, stalinizmu i nazizmu (o. Woroniecki).

\section{b) Pochodzenie społeczne}

Ksiądz Ślósarz urodził się w ubogiej wiejskiej rodzinie w Węglówce w powiecie myślenickim. Do 13 roku życia pomagał $\mathrm{w}$ gospodarstwie, potem skończył czteroklasową szkołę w Myślenicach. Gimnazjalne wykształcenie zdobył w Rzeszowie i Brzeżanach dzięki możliwości mieszkania u stryja, o. Juliana, bernardyna. Pod jego wpływem został księdzem.

Adam Marian Tomasz Pius Leon książę Korybut Woroniecki pochodził $\mathrm{z}$ rodu kniaziów Nieświckich. Urodził się w Lublinie, dorastał w majątku Kanie k. Chełma. Wykształcenie zapewniono mu, sprowadzając z Anglii guwernantkę. Potem uczył się w IV Gimnazjum Męskim w Warszawie. Następnie ojciec, książę Korybut Woroniecki, skierował go do pułku huzarów grodzieńskich w Warszawie i na Uniwersytet we Fryburgu w Szwajcarii. Po śmierci ojca Jacek zmienił wydział na teologiczny i wstąpił do żebraczego zakonu dominikanów. Ojciec by mu na to nie pozwolit.

\section{c) Praca pedagogiczna}

Obaj formułowali wskazówki pedagogiczne na bazie pracy z młodzieżą, postrzegali je priorytetowo i w perspektywie społecznej. Ksiądz Ślósarz był katechetą w III, IV i v Gimnazjum oraz w C.K. I Wyższej Szkole Realnej we Lwowie. Obowiązki katechety pełnił 18 lat, przetłumaczył katechizm z j. niemieckiego ${ }^{8}$, potem napisał nowy ${ }^{9}$, który miał trzy wydania i był używany również w innych szkołach. Wygłosił referat na I Zjeździe Katechetów w Krakowie w 1895 roku i współorganizował II Zjazd Księży Katechetów we Lwowie

\footnotetext{
${ }^{8}$ Mały katechizm religii rzymsko-katolickiej przełożył z niemieckiego tekstu Jan Ślósarz, Lwów 1898.

Ks. J. Ślósarz, Katechizm religii katolickiej dla młodzieży szkót średnich, Lwów 1897. Podręcznik miał trzy wydania. Fragment: http://ultramontes.pl/grzechy_przeciwko_wierze.htm (10.09.2017).
} 
w 1897 roku $^{10}$. Pozycja katechety była niska, szkoły przepełnione, a nauczanie religii w wielokulturowej społeczności trudne ${ }^{11}$.

Zadbał, by pracę pedagogiczną w jego rodzinnej Węglówce prowadziły siostry ze zgromadzenia założonego przez arcybiskupa Zygmunta Szczęsnego Felińskiego. Realizowały intencje założyciela, urodzonego na Wołyniu, który w wieku 16 lat doświadczył zesłania matki na Syberię za przywiązanie do polskości i który potem pracując 12 lat w lwowskiej diecezji jako rzecznik ewangelicznego braterstwa Polaków i Ukraińców, powierzył temu zakonowi wychowanie dzieci i młodzieży. Ksiądz Ślósarz postawił więc na apostoła pokoju, jedności i zgody narodowej $j^{12}$. Był też adiunktem, zastępcą profesora historii kościelnej i docentem prywatnym teologii pastoralnej na $\mathrm{Wy}$ dziale Teologicznym Uniwersytetu Lwowskiego oraz prefektem alumnów w lwowskim Arcybiskupim Seminarium Duchownym dla Kleryków.

Ojciec Woroniecki wykładał etykę w krakowskim Studium Generale Zakonu Dominikanów (1914-1919), teologię moralną i etykę na Katolickim Uniwersytecie Lubelskim (od 1919, gdy pomagał w jego utworzeniu), teologię moralną i pedagogikę w Collegium Angelicum w Rzymie. We Lwowie został kierownikiem dominikańskiego studium filozoficzno-teologicznego i wykładowcą teologii moralnej. Założył Zgromadzenie Sióstr Dominikanek Misjonarek Jezusa i Maryi mające za zadanie ewangelizację Rosjan. Po upadku zSRR siostry założyły placówki w Orle (Rosja), Fastowie, Kijowie i Rokitnie (Ukraina), Lipawie, Kuldidze (Łotwa).

${ }_{10}$ Por. ks. J. Wołczański, Ślósarz Jan ks., w: Polski słownik biograficzny, t. LI / 1, zesz. 208, red. A. Romanowski, Warszawa-Kraków 2016, s. 42.

${ }^{11}$ Por. np. Statystyka zakładu. Skład grona nauczycielskiego z końcem roku szkolnego 1894/5, w: Dwudzieste drugie sprawozdanie Dyrekcyi C. K. Wyższej Szkoły Realnej we Lwowie za rok szkolny 1895, s. 43-45, Lwów 1895, poz. 14, http://www.pbc.rzeszow.pl/publication/5009 (29.10.2017). Katecheta wymieniony jest na 44. stronie dokumentu, podobnie w innych sprawozdaniach $\mathrm{z}$ tego okresu. Natomiast w Sprawozdaniu Dyrekcyi Państwowego Gimnazjum IV im. Jana Długosza we Lwowie za rok szkolny 1931/32 w rozdziale I. Skład grona nauczycielskiego przy końcu roku szkolnego 1931-1932 katecheta wymieniony jest na czwartej stronie (pierwszej ciągłego tekstu), zaraz po dyrektorze i nauczycielu języka polskiego, na s. 9 zamieszczono sprawozdanie z działalności Sodalicji Mariańskiej oraz Kółka Mariańskiego - a dopiero potem innych szkolnych organizacji. Świadczy to o deprecjonowaniu katolicyzmu przez zaborców oraz o przywiązywaniu do niego wielkiej wagi przez władze Polski odrodzonej po 1918 roku.

${ }^{12}$ Cytat $\mathrm{z}$ listu polskiego Episkopatu, napisanego z okazji kanonizacji św. Zygmunta Szczęsnego Felińskiego w 2009 roku za: BP KEP, Patron na czasy trudne - abp Zygmunt Szczęsny Feliński, https:// kosciol.wiara.pl/doc/491079.Patron-na-czasy-trudne-abp-Zygmunt-Szczesny-Felinski (15.07.2018). 


\section{d) Odmienność koncepcji pedagogicznych}

Ksiądz Ślósarz został skierowany do Wiednia, gdzie uzyskał doktorat z teologii w 1885 roku, a habilitował się w 1901 roku z teologii pastoralnej pracą O cenzurach kościelnych, w szczególny sposób Papieżowi zastrzeżonych ${ }^{13}$, w której uporządkował i opisał kary kościelne (z ekskomuniką włącznie) grożące za wykroczenia duchownych i świeckich, precyzując, na jakich zasadach i przez kogo przewinienia mogą być odpuszczane.

Ojciec Woroniecki otrzymał doktorat z teologii w 1909 roku w Szwajcarii. W Collegium Angelicum w Rzymie uzyskał najwyższy u dominikanów tytuł mistrza świętej teologii. W Katolickiej etyce wychowawczej ${ }^{14}$ sformułował teologicznie uzasadnione, ojcowskie wskazówki postępowania w skomplikowanych sytuacjach etycznych, zaadresowane dla katolików różnych stanów, zwłaszcza żyjących w warunkach ustrojowych PRL.

\section{e) Ratowanie materialnej bazy kościoła}

Ksiądz Ślósarz rozpoczął uwieńczone sukcesem starania o odzyskanie lwowskich kościołów św. Klary i św. Wojciecha przekształconych w magazyny, ufundował kościół i plebanię w Węglówce oraz zadbał o utworzenie w niej parafii.

Ojciec Woroniecki w porozumieniu z generałem zakonu o. Marcinem S. Gilletem podjął decyzję o skierowaniu duszpasterskiej działalności dominikanów na środowiska w centralnej Polsce, co wymagało sprzedaży znajdujących się na Kresach majątków dominikańskich, aby zyskać środki na kupno placu na warszawskim Służewie w 1934 roku i zbudowanie na nim klasztoru. Pełnił funkcję syndyka. Plan zrealizowano.

\section{f) Śmierć wśród najbliższych i pochówek w kościele}

Oderwali się od swych rodzin i kręgów społecznych, aby być pożytecznymi dla szerszych środowisk. Ostatnie dni życia spędzili wśród najbliższych. Ksiądz Ślósarz śmiertelnie zachorował w rodzinnej Węglówce. Pochowano go w kościele, którego był fundatorem. Ojca Woronieckiego II wojna zastała w dominikańskim klasztorze w Krakowie i tam po ciężkiej chorobie zmarł. Jako

${ }_{13}$ Ks. J. Ślósarz, O cenzurach kościelnych i ekskomunikach w szczególny sposób Papieżowizastrzeżonych, Lwów 1900, http://dlibra.kul.pl/dlibra/docmetadata?id=1670\&from=pubindex\&dirids $=42 \& l p=587$ (12.07.2018).

${ }^{14}$ J. Woroniecki op, Katolicka etyka wychowawcza, t. 1: Etyka ogólna, Lublin 1995; J. Woroniecki oP, Katolicka etyka wychowawcza, t. 2: Etyka szczegółowa. Część 1, Lublin 1995; J. Woroniecki op, Katolicka etyka wychowawcza, t. 2: Etyka szczegółowa. Część 2, Lublin 1995. 
członka rodziny zakonnej pochowano go w zbiorowym grobowcu oo. Dominikanów usytuowanym na Cmentarzu Rakowickim, a w 1960 roku prochy złożono w kościele św. Jacka w Warszawie i wmurowano tablicę pamiątkową.

\section{g) Kontrowersje}

Obaj mieli radykalne poglądy i byli aktywni w sferze organizacyjnej, toteż zyskali wrogów. Anonimowy autor zarzucił księżom-doktorom - zatem też ks. Ślósarzowi - że za mało publikują, na co ten odpowiedział artykułem O doktorach nie literatach ${ }^{15}$. Atakowany był też przez radykalizujących uczniów za prezentowanie na lekcjach religii lojalnego stosunku do zaborczej władzy Adam Uziembło nazwał go „beznadziejnie głupim”16.

Natomiast o. Woronieckiego krytykowano za sprzedaż kresowych majątków zakonu, którą interpretowano jako „wyzbywanie się narodowego dziedzictwa na rzecz Ukraińców i Żydów”17. Nie był pewien kanoniczności swych nowatorskich publikacji, dlatego na łożu śmierci martwił się:

Ojcze przeorze, trochę się boję, bo człowiek pisał te książki i czy ja to dobrze napisałem? Boję się teraz sądu Bożego ${ }^{18}$.

h) Wniosek: podobieństwo koncepcji pedagogicznych mimo biograficznych różnic

Ksiądz Ślósarz i o. Woroniecki analizowali i wyjaśniali prawne normy oraz zasady pedagogiczne obowiązujące katolików. Obaj prezentowali osobowości

autonomiczne, zaradne, aktywne, zdolne do podejmowania wyborów i gotowe do realizacji własnych projektów działania ${ }^{19}$.

15 Ks. J. Ślósarz, O doktorach nie literatach, „Gazeta Kościelna” 24 (1917) nr 13, s. 150-151.

16 A. Uziembło, Wspomnienia lwowskie, red. D. Maciak. Z fragmentów zestawiła A. Uziembło, „Przegląd Wschodni” 8 (2001) zesz. 2, s. 485.

${ }_{17}$ Za: M. L. Niedziela op, Próba biografii Jacka Woronieckiego op i jego Wyznania, Lublin 2011, s. 261 .

${ }_{18}$ Wywiad $z$ bratem D. Michalczewskim op, Kraków 2.07.1998 [wywiad na temat o. Woronieckiego udzielony o. M. L. Niedzieli op w Klasztorze oo. Dominikanów w Krakowie, spisany z nagrania przez A. Ślósarz].

19 M. Czyżewski, Socjologia interpretatywna i metoda biograficzna: przemiana funkcji, antyesencjalistyczne wątpliwości oraz sprawa krytyki, „Przegląd Socjologii Jakościowej” 9 (2013) nr 4, s. 22. 
Reprezentowali osobowości „uspołecznione”. Wiązali pracę pedagogiczną z naukową i organizacyjną, przyczyniając się do wprowadzania radykalnych zmian w bliższym i dalszym otoczeniu. Zmiany te miały wymiar cywilizacyjny w odniesieniu do mieszkańców Węglówki (ks. Ślósarz) i polskiej inteligencji katolickiej (o. Woroniecki).

\section{Różnice odzwierciedlone w portretach}

Założono, że ikonosfera jest reprezentacją zbiorowej świadomości, zatem obraz pozwala dotrzeć do ludzkich pojęć i wyobrażeń, a fotografia jako semiotycznie nacechowany kulturowy komunikat odzwierciedla ludzkie doświadczenia i wierzenia - widzialne i ukryte elementy rzeczywistości ${ }^{20}$.

\section{a) Portret ks. Ślósarza - zwrot do tradycji}

Portret ks. Ślósarza, zawieszony na ścianie węglowskiego kościółka namalował polski portrecista i pejzażysta Aleksander Augustynowicz, który w latach 1890-1914 mieszkał we Lwowie.

Wizerunek mógł powstać po 1906 roku, w którym ks. Ślósarz otrzymał godność kanonika. Być może pozował w pracowni, ponieważ mieszkał we Lwowie od 1875 roku. Jest to jednak mało prawdopodobne $z$ uwagi na jego obciążenia różnorodnymi obowiązkami. Wizerunek mógł być przygotowany na podstawie fotografii. Była wtedy nisko ceniona, toteż portret fotograficzny nie wchodził w grę. Wartość dokumentalną zaczęto przypisywać fotografii dopiero w latach dwudziestych $\mathrm{xx}$ wieku ${ }^{21}$. Natomiast w portrecie od wieków chodziło o przekazanie symbolicznych treści, niedosłownych informacji o osobie. Zapewne dlatego wykorzystano technikę malarską, a nie fotografię, powstającą i blednącą pod wpływem światła, wilgoci, podatną na zniszczenie. Powstała ona w czasach dynamicznego rozwoju wielkich miast, masowej produkcji i narodzin nowych ideologii. Wnosiłaby niepożądane treści do portretu kanonika i odciętej od świata wioski, zwłaszcza że:

Era Fotografii jest także erą rewolucji, protestów, zamachów, wybuchów, krótko mówiąc - niecierpliwości, wszystkiego tego, co zaprzecza dojrzewaniu ${ }^{22}$.

${ }^{20}$ Por. K. Leśniak, Dyskusje nad pojęciem i istota dokumentu fotograficznego, "Quart” 2010 nr 4 (18), s. 86.

${ }^{21}$ Por. K. Leśniak, Dyskusje nad pojęciem i istotą dokumentu fotograficznego..., dz. cyt., s. 84 .

${ }^{22}$ R. Barthes, Światło obrazu. Uwagi o fotografii, przeł. J. Trznadel, Warszawa 1992, s. 159. 


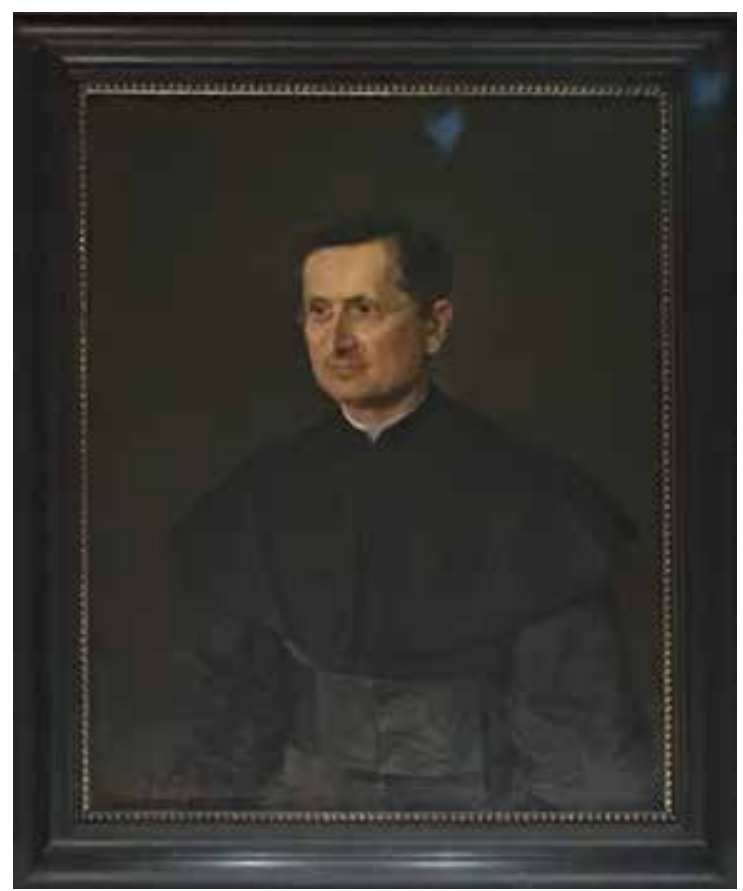

Ilustracja 1. Portret ks. Ślósarza w kościele pw. MB Anielskiej w Węglówce.

Fot. A. Ślósarz

Portret ks. Ślósarza został zaprojektowany jako pomnik, który ma unaocznić jego zasługi i przetrwać lata. Augustynowicz namalował go w konwencji antycznych popiersi twórców, wodzów, polityków.

Nie wiadomo, czy portretowany stoi, czy też siedzi. Przywilej portretowania się w pozycji siedzącej przysługiwał tradycyjnie zasłużonym i najgodniejszym, tymczasem portretowany był stosunkowo młody. Portrecista wyeksponował jego profil, który zapewne był rozpoznawany przez najbliższą rodzinę jako cecha rodowa. Również we wspomnieniach Uziembły wizerunek sylwetki ks. Ślósarza utrwalił się wraz z charakterystycznym profilem:

Wysoki, wrzecionowaty, nieco rozdęty w okolicy żołądka, zwężał się ku górze, ku niedużej głowie, w której dominował zakrzywiony nos i duże okulary ${ }^{23}$.

${ }^{23}$ A. Uziembło, Wspomnienia lwowskie..., dz. cyt., s. 484. 
Portretowany przedstawiony został w drucianych okularach i dokładnie ogolony. Włosy ma starannie przystrzyżone. Na skroniach już przerzedzone, lecz pozostały ciemne. Prawdopodobnie jest w sile wieku, ale nie wiadomo, na ile przedstawienie jest wiarygodne i z którego roku pochodzi. $\mathrm{Na}$ jednej $\mathrm{z}$ rodzinnych fotografii, wykonanych pod koniec życia księdza podczas pobytu w Węglówce, jego włosy są siwe, dłuższe i mniej starannie ułożone - zapewne wskutek zaawansowanego wieku, gdyż wspiera się na lasce. Okularów nie widać. Podczas pobytu w Węglówce zaabsorbowany był zakładaniem nowego kościoła i organizowaniem parafii, a nie pracą naukową.

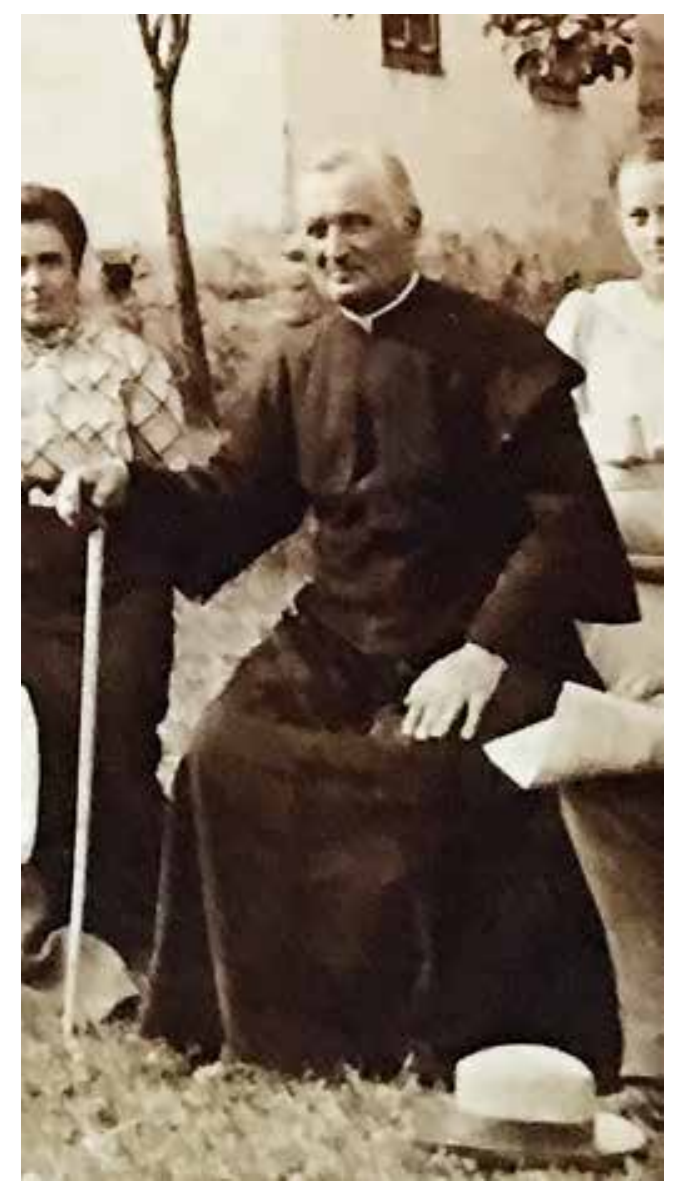

Ilustracja 2. Fotografia ks. Ślósarza, fragment zbiorowego zdjęcia z ok. 1910 roku. Fotograf nieznany 
Zarówno na portrecie, jak i na fotografii widać, że ks. Ślósarz jako kanonik na czarnej sutannie nosił mucet (a. muncet), czyli zakrywającą ramiona czarną pelerynkę, zapinaną pod szyją. Na portrecie odcina się ona głęboką czernią od reszty sutanny, zwłaszcza lśniącego, szerokiego pasa. Portretowany uważnie wpatruje się w przestrzeń po swej prawej stronie, a piwne tęczówki wyraźnie określają kierunek spojrzenia. Podobnie jak na rodzinnym zdjęciu jest wychylony do przodu, przez co mucet odchyla się od sutanny. Wychylenie to może wyrażać jego pionierskie zaangażowanie na polach: wspierania katolickiej doktryny (jako teologa), organizowania materialnej bazy kościoła (jako kanonika) i podnoszenia poziomu życia na prowincji (jako węglowianiana).

$\mathrm{Na}$ obu przedramionach portretowanego widać zapięcia szerokich rękawów wykończone czarnymi guziczkami. Dziś taki krój sutanny nie jest używany. Niecodzienne elementy ubrania nadają więc sylwetce kanonika odświętny wygląd i charakter wyjątkowej postaci, dla ówczesnych węglowian zapewne egzotycznej.

\section{Percepcja i rozpowszechnianie portretu}

Portret umieszczono w kościele. Oglądany jest przez ludzi rozmodlonych, patrzących od dołu (czyli z tzw. żabiej perspektywy), co monumentalizuje portretowanego i odzwierciedla jego społeczny awans. Wizerunek odnowiono, zaopatrzono w ramy. Jest otaczany gałązkami, kwiatami, zniczami i oświetlony kinkietem, co wyraża szacunek pokoleń dla księdza rodaka. Portretowany jest wyprostowany, spogląda w daleką przestrzeń zza okularów i z wysoka. Odzwierciedla to jego dystans do świata, a zwłaszcza zła, którego - jak wynika z publikacji - nie starał się usprawiedliwiać. Zwrócenie sylwetki odwrotnie do kierunku czytania świadczyć może o nieakceptowaniu biegu historii, który oglądał w przedrewolucyjnym Lwowie.

Twarz i postać portretowanego otoczone są rozproszonym światłem, które „zmiękcza obraz, jakby delikatnie ogarniając go ze wszystkich stron naraz”24. Dzięki takiemu oświetleniu twarz zaprezentowana została jako spokojna i łagodna - taki też zapewne stosunek miał do rodziny i parafian z Węglówki, dla których portret przeznaczył.

Brak tła wizerunku mógł wyniknąć z niemożności dookreślenia społecznych ról sportretowanego ${ }^{25}$. Zawierały się one bowiem w wielu kategoriach:

${ }^{24}$ Por. J. Płażewski, Język filmu, Warszawa 1982, s. 409.

25 Artysta ten nie namalował też tła własnego autoportretu z 1895 roku - por. A. Augustynowicz Autoportret, http://www.kultura.malopolska.pl/record/-/record/aggregated97051/o/o/12/2/5/ 
1. Księdza, prefekta seminarium, dziekana, egzaminatora prosynodalnego, asesora sądu Metropolitalnego, kanonika.

2. Uniwersyteckiego wykładowcy, docenta, tłumacza, publicysty, autora podręcznika i książek.

3. Katechety, delegata Kurii Biskupiej w Przemyślu do stałej komisji układania planów i aprobowania podręczników, sekretarza Towarzystwa Bursy św. Wojciecha, rektora kościoła i internatu.

4. Fundatora kościoła.

5. Przedstawiciela katolików, którzy odzyskali dwa lwowskie kościoły.

6. Członka Zarządu Głównego Kółek Rolniczych we Lwowie, referenta oraz delegata lwowskiej Kurii Metropolitalnej do Kółek Rolniczych i Związków Parafialnych, inicjatora budowy lokalnych dróg, propagatora nowoczesnych metod uprawy roli i zakładania sadów owocowych, komisarza do szkół ludowych, węglowianina.

Otaczające portretowanego rozproszone światło obrazuje wieloaspektowość jego aktywności i mnogość środowisk, wśród których działał. Był zaangażowany duszpastersko jako ksiądz, pedagog, katecheta, autor. Aktywny do końca życia: przeziębiwszy się wskutek towarzyszenia węglowianom pracującym przy osuszaniu kościoła ${ }^{26}$, zmarł po kilku dniach.

Wielość społecznych ról ks. Ślósarza została natomiast dookreślona w fotomontażu, umieszczonym na zaproszeniu na sesję zorganizowaną dla uczczenia stulecia jego śmierci. Sylwetka znalazła się na tle współczesnego widoku założonego przez niego kościoła, a rękaw sutanny przysłonięto, eliminując wrażenie jej dawności.

Podobny sposób portretowania zastosowano na początku filmu na temat ufundowanego przez ks. Ślósarza kościoła. Portret opatrzono podpisem i skadrowano jak legitymacyjne zdjęcie. Strój pozbawiono więc atrybutów dawności. Wpisując wizerunek w tendencję współczesnych mediów elektronicznych do aktualizacji przekazywanych treści, wytworzono wrażenie, że sutanna ma taki sam krój, jak noszone współcześnie przez katolickich księży, w tym sercanów z Węglówki.

importDate/desc?query=MEGA:\%22Augustynowicz\%20A\%22\%2OAND\%2oflag:\%22hasmedia\%22?p_ auth $=47$ CvcLrs (13.08.2018). Malarza charakteryzują trzymane w ręku pędzle, nonszalancka poza, oryginalna fryzura i modne ubranie. Sportretował się w pozycji stojącej, co według portretowych konwencji wyraża skromność.

${ }^{26}$ Por. Ks. K. Jastrzębski, Ks. dr Jan Ślósarz, Archiwum Parafialne w Węglówce, s. 3. 

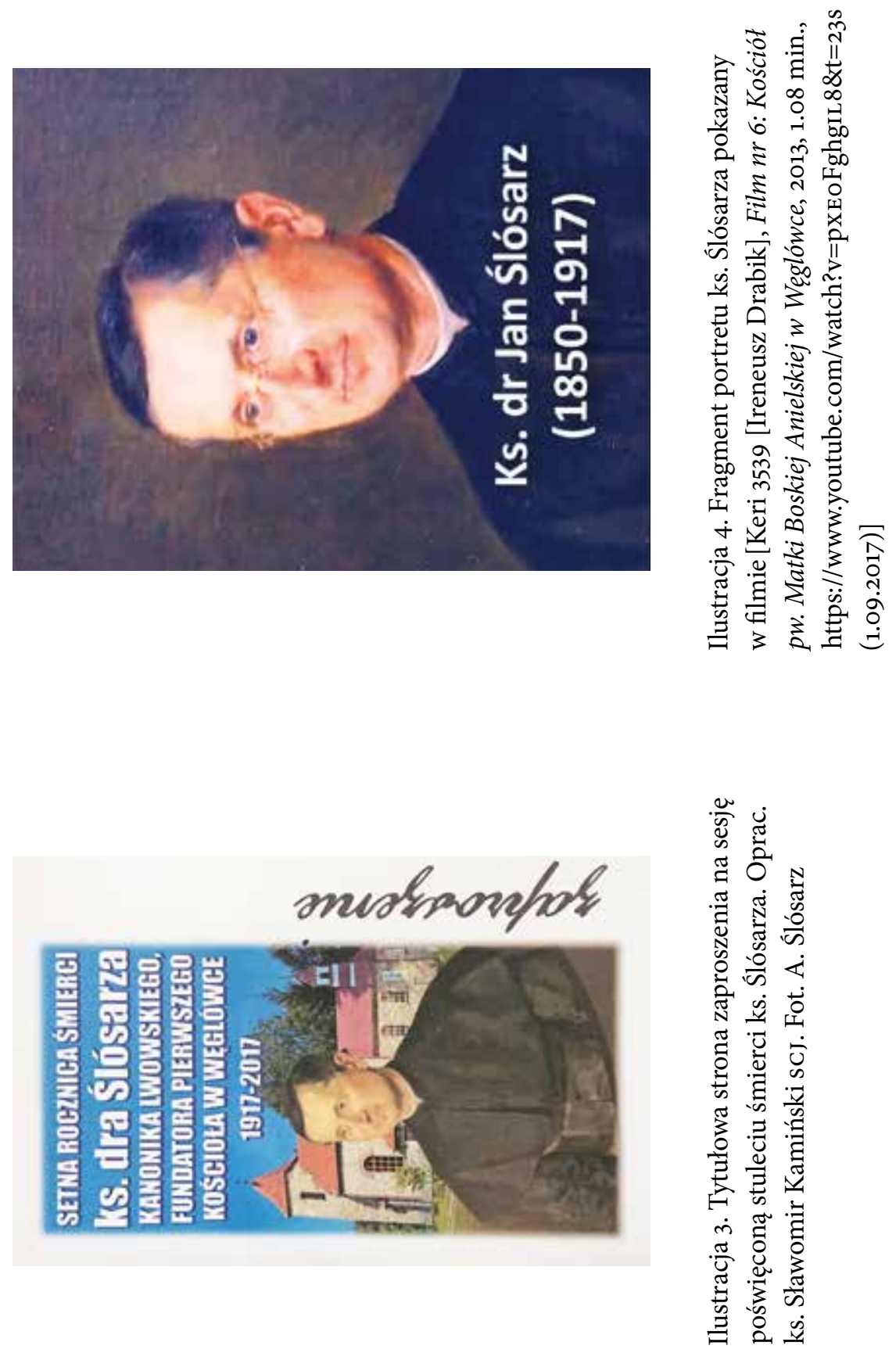
Pojawiające się potem ujęcia dłużej eksponują epitafijną tablicę niż portret, pokazany tylko w planie ogólnym. Archaiczne elementy stroju stały się trudno rozpoznawalne.

Najważniejszy portret ks. Ślósarza przygotowano w miejscu świeckim, zaadresowano do niewielkiego grona przedstawicieli węglowskiej społeczności i umieszczono w przestrzeni sakralnej - wtórnie w Internecie.

\section{Portret - element pamięci zbiorowej}

Późniejsze zdjęcie ks. Ślósarza stało się elementem kompozycji złożonej z pięciu portretów tej samej wielkości, w takich samych ramkach, oszklonych i wyposażonych w uchwyty do zawieszania. Wykonanie zleciła więc osoba, której zależało na podtrzymywaniu pamięci o rodzinnej tradycji. Pojedyncze portrety bywają zawieszane na ścianach mieszkań w rodzinie Ślósarzów ${ }^{27}$ lub przechowywane $\mathrm{w}$ formacie zbliżonym do pocztówkowego jako rodzinne pamiątki.

Kompozycję rozpoczyna o. Julian Ślósarz. Naprzeciwko umieszczono portret jego bratanka, ks. Ślósarza. W niższym rzędzie - jak w kolejnej gałęzi drzewa genealogicznego - portrety księży z kolejnych pokoleń i linii rodowych. Układ wyraża zasługi o. Juliana i ks. Jana co do liczby powołań w rodzinie. Ich liczba wzrosła też w wiosce.

Ksiądz Ślósarz został sportretowany jako człowiek dojrzały. Siwiejące włosy ma gładko zaczesane, twarz ogoloną. Wykadrowanie sprawiło, że mucet stał się mało dostrzegalny, więc rozjaśniono krawędzie i podkreślono załamanie zapięcia sutanny, aby go uwidocznić. Portretowany patrzy lekko do góry, co może wyrażać jego zapatrzenie w ideały i dystans do przyziemnych spraw, w tym niezrozumienia ze strony ulegających bolszewickiej ideologii uczniów i węglowian oczekujących budowy drugiego kościoła na dole wioski. Kieruje niejako spojrzenie do o. Juliana. Załamanie sutanny świadczy, że podczas wykonywania fotografii prawdopodobnie siedział, symbolicznie wyrażając w ten sposób swą stabilizację w tym momencie życia. Mocny retusz, sztuczna poza i prześwietlone brzegi zdjęcia świadczą, że fotograf wykonywał konwencjonalne portrety, wpisując się w standardowe oczekiwania klientów.

${ }^{27}$ Na przykład mój teść Tadeusz Ślósarz (1913-1998) nie rozstawał się z przedstawiającym o. Juliana obrazem, który zawsze wisiał w jego pokoju. Związek z o. Julianem wyrażał też uczestnictwem w niedzielnych mszach św. w krakowskim kościele oo. Bernardynów. 


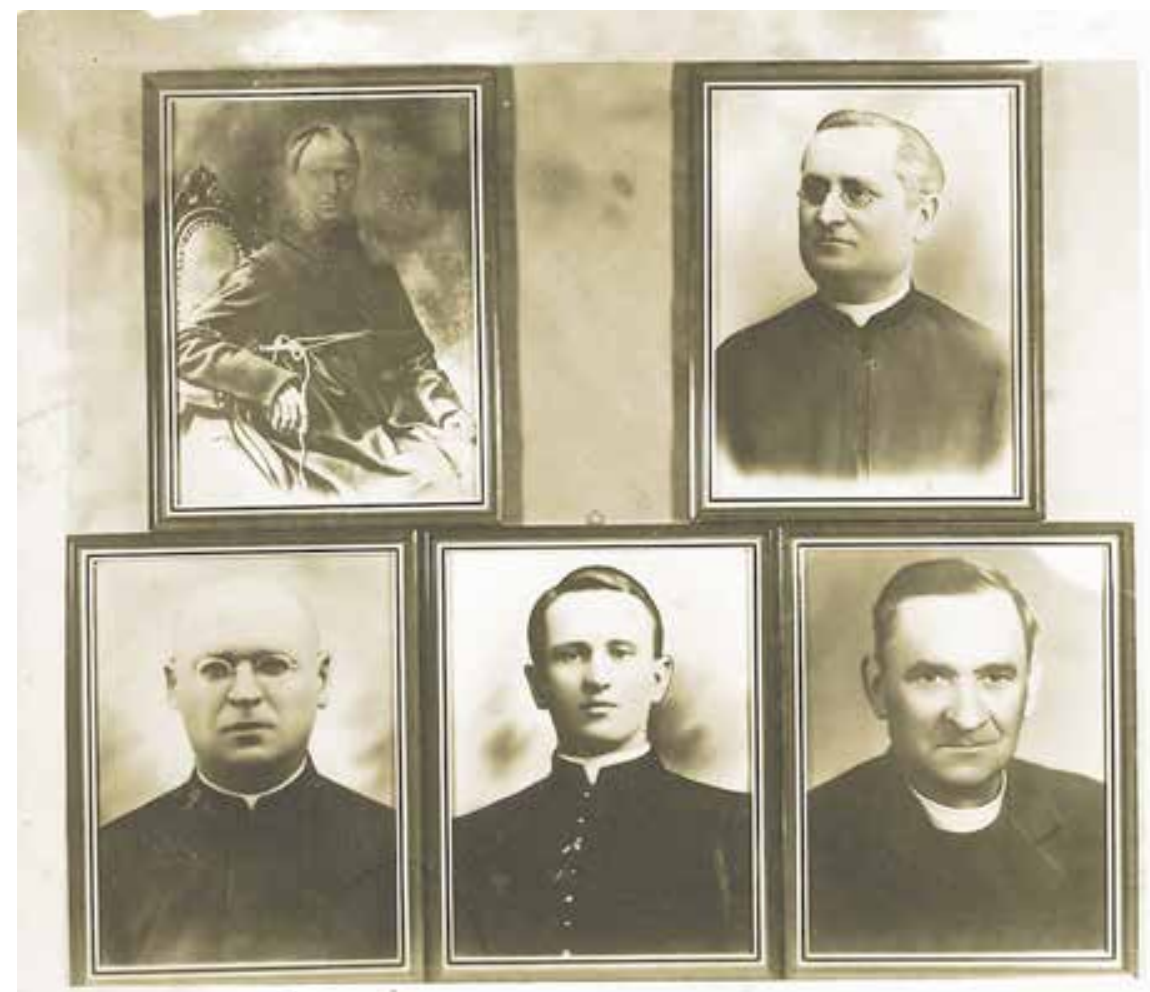

Ilustracja 5. Portrety księży z rodu Ślósarzów. Od lewej w górnym rzędzie: o. Julian Ślósarz, ks. Jan Ślósarz. Niżej od lewej: ks. Marcin Ślósarz, ks. Stanisław Węglarz, ks. Marcin Bardel (więzień Dachau). Autor fotografii nieznany

Kompozycja wyraża przywiązanie jej autora do rodzinnej tradycji. Została zreprodukowana przed wstępem w książce ks. Marcina Bardela ${ }^{28}$.

$\mathrm{Na}$ ostatnim prawdopodobnie portrecie ks. Ślósarza fotograf jak na innych wizerunkach zatarł rękawy sutanny, eksponując mucet. Siwe włosy świadczą o zaawansowanym wieku portretowanego. Jego twarz jest nabrzmiała - dokuczała mu astma ${ }^{29}$. Podniesiony wzrok wyraża jednak dystansowanie się od przyziemnych problemów. Nieruchome spojrzenie w dal, podobnie jak na wcześniejszych portretach, wyraża, że jest

${ }^{28}$ Ks. M. Bardel, Z Krasnobrodu przez obozy i obczyznę do rodzinnych stron, Lublin 1994, s. 6.

${ }^{29}$ Por. Ks. K. Jastrzębski, Ks. dr Jan Ślósarz..., dz. cyt., s. 3. 
zorientowany na przyszłość, gotowy do niesionych przez nią wyzwań, zdeterminowany, elastyczny, pragnący zmian ${ }^{30}$.

Patrzenie $\mathrm{w}$ dal wyklucza wchodzenie $\mathrm{z}$ potencjalnymi widzami w interak$\mathrm{cje}^{31}$. Padające $\mathrm{z}$ góry światło wyraża inspirację wyższymi ideałami, a ciemne tło można odnosić do otaczającego zła.

Ksiądz Ślósarz jest pokazany jak na portrecie Augustynowicza: z daleka i w konsekwencji od pasa w górę, ponieważ, jak zauważa Krzysztof Olechnicki:

Osoby postawione wyżej w hierarchii społecznej, w pełni „cywilizowane”, pozowały [...] spoglądając z dystansem, na bok albo do góry, lecz w żadnym razie nie pozwalając aparatowi zbytnio się zbliżyć i naruszyć swojej prywatności ${ }^{32}$.

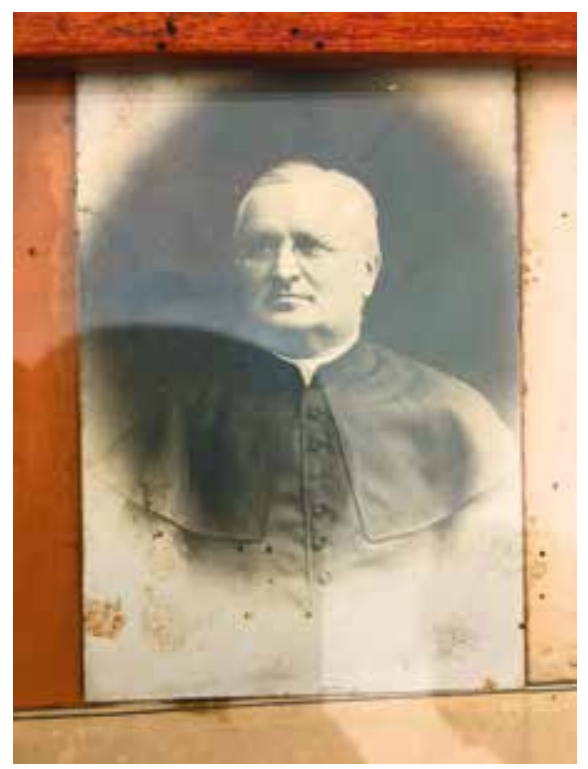

Ilustracja 6. Późny portret ks. Ślósarza wykonany przez nieznanego fotografa. Fot. A. Ślósarz

${ }^{3}$ Por. K. Olechnicki, Antropologia obrazu. Fotografia jako metoda, przedmiot i medium mauk społecznych, Warszawa 2003, s. 243.

${ }_{31}$ Por. K. Olechnicki, Antropologia obrazu..., dz. cyt., s. 241.

32 K. Olechnicki, Antropologia obrazu..., dz. cyt., s. 243. 
Zdjęcie naklejono na tekturkę, oprawiono w ramki i oszklono wraz z fotografiami z pierwszego odpustu w Węglówce oraz zbiorowym portretem przedstawiającym ks. Ślósarza w otoczeniu najbliższej rodziny. Zaplamienia świadczą o warunkach, w jakich żyli właściciele fotografii, a podziurawiona przez korniki ramka o tym, że zdjęcia te towarzyszą im przez wiele lat jako pamiątka po kapłanie, którego uznali za swego dobrodzieja. Fotografii nie umieszczono w rodzinnym albumie, lecz jako wyjątkowo cenne wyeksponowano na ścianie rodzinnego domu. Funkcjonują w środowisku węglowskich katolików i ich potomków - zostały przywiezione ze Śląska na sesję poświęconą uczczeniu setnej rocznicy śmierci ks. Ślósarza. Zapewne były pokazywane dzieciom oraz znajomym. Wytwarzały poczucie wspólnoty, określając pochodzenie i wyznanie właścicieli - współtworzyły kapitał kulturowy w postaci indywidualnej i zbiorowej pamięci oraz tożsamości. Odwołując się do interpretacji ikonologicznej w ujęciu Erwina Panofsky’ego, stwierdzić więc można, że fotografia ta jest fenomenem kulturowym, ponieważ odzwierciedliła

fundamentalną postawę narodu, okresu historycznego, klasy, przekonań religijnych lub filozoficznych, wartościowane przez pewną osobowość i skupione w jednym dziele ${ }^{33}$.

Wniosek: wieloaspektowa aktywność ks. Ślósarza Ze sposobu wykonania i praktyk prezentowania portretów ks. Ślósarza można wywnioskować, że współdziałał on z szerokim otoczeniem jako silny, krytyczny i skuteczny w działaniu człowiek czynu, aktywny na wielu polach. Sutanna i mantolet włączają go do katolickiego duchowieństwa - i rzeczywiście w działaniach i swych najważniejszych publikacjach odnosił się do doktryny Kościoła katolickiego, który stawał w obliczu złożonych wyzwań.

Miejsce śmierci, pochówku i umieszczenia portretu z pamiątkową tablicą świadczą, że utrzymał też związki z miejscem pochodzenia i rodziną, zajmując w ich dziejach poczesne miejsce ${ }^{34}$.

33 E. Panofsky, Ikonografia i ikonologia, przeł. K. Kamińska, w: E. Panofsky, Studia z historii sztuki, oprac. J. Białostocki, Warszawa 1971, s. 13.

${ }^{34}$ Kamienne epitafium upamiętniające ks. Ślósarza umieszczono też na ścianie odzyskanego przez niego kościoła św. Wojciecha, przeznaczonego dla gimnazjalistów. Por. ks. K. Jastrzębski, Ks. dr Jan Ślósarz..., dz. cyt., s. 4 . 
b) Portretowa fotografia o. Jacka Woronieckiego

Ojciec Woroniecki sprawia na fotografii wrażenie człowieka zrezygnowanego, słabego i chorego. Zapadnięte oczy w czarnych cieniach, bezwładne ręce, złożone niemalże jak w trumnie i zgarbiona, wątła sylwetka kontrastująca z nieproporcjonalnie dużą, przerysowaną perspektywicznie głową świadczą o braku siły. Tło sugeruje, że zdjęcie wykonano niespodziewanie, może podczas chwili odpoczynku, prawdopodobnie w pomieszczeniu należącym do klasztoru (przestrzeni sakralnej). Lśniące elementy przy lewej krawędzi zdjęcia prawdopodobnie znalazły się w kadrze przypadkowo, nie zostały bowiem wkomponowane jako istotny element fotografii. Portretowany nie był zatem do portretu przygotowany. Nosi codzienny, biały, dominikański habit, czysty i uprasowany, być może w świąteczny dzień. Fotografujący nie śmiał zakłócać odpoczynku i wykonał zdjęcie siedzącej postaci, prawdopodobnie stojąc, więc spoglądamy na portretowanego z bocianiej perspektywy, przez co został pomniejszony. Perspektywa ta odzwierciedla społeczną degradację arystokraty, który wstąpił do żebraczego zakonu. Fotografia znajduje się w „Wikipedii”, świeckiej i dostępnej na całym świecie, lokalizując postać w kontekście codziennych czynności użytkownika, w sąsiedztwie przypadkowo dobranych grafik i przedmiotów.

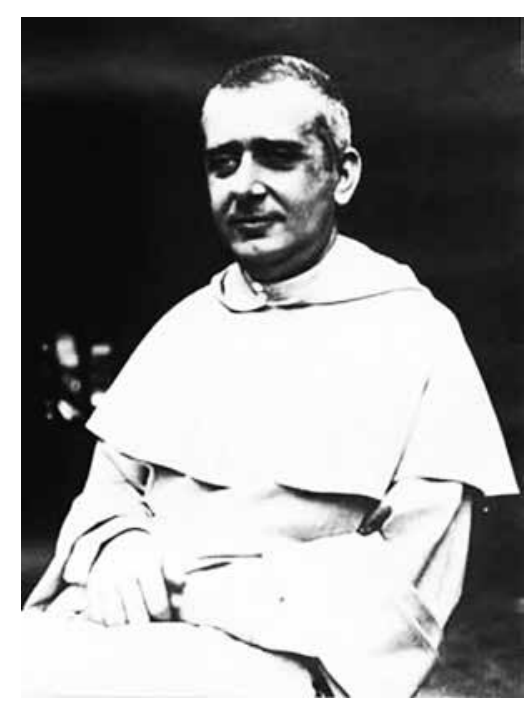

Ilustracja 7. O. J. Woroniecki. Zdjęcie sprzed roku 1930

[Źródło: Jacek Woroniecki, https://pl.wikipedia.org/wiki/Jacek_Woroniecki (24.10.2017)] 
Rozpowszechnianie i percepcja portretu

Zdjęcie umieścili warszawscy dominikanie (Maksymilian Sielicki) w „Wikipedii”, w 2015 roku, w wolnym dostępie i wysokiej rozdzielczości. Wykonane przed 1930 rokiem zdjęcie podpisano „Jacek Woroniecki uśmiechnięty”, choć sfotografowany grymas trudno nazwać uśmiechem. Niekorzystne, ostre, górne oświetlenie uwydatnia zmarszczki, podkreśla kontrasty i tworzy efekt niesamowitości, tak samo jak w powstających wówczas w Niemczech ekspresjonistycznych filmach o mrocznej, często kryminalnej tematyce ${ }^{35}$. W tych samych latach dwudziestych amerykańskie kino gangsterskie portretowało świat, w którym według Marioli Jankun-Dopart „nie może być mowy o zwycięstwie dobra i sprawiedliwości"36.

Oświetleniem wydobyto kontrast między białym habitem i czarnym tłem, nawiązując zarówno do czarno-białych strojów i herbów dominikanów. Wytworzono efekt dramatyczny: powstało wrażenie, że siedzącego osacza niebezpieczeństwo lub zło, którego ataku atawistycznie spodziewamy się z ciemności. Portretowany wydaje się tym przytłoczony i jest fizycznie wyczerpany. Zdjęcie mogło być wykonane w okresie jego wykładów w Rzymie, które musiał przerwać z powodu złego stanu zdrowia i wrócić do Polski.

Nie wiadomo, czy ktoś siedział naprzeciwko portretowanego, czy też była przed nim tylko równie ciemna pustka, do której się „uśmiechał”, pozując do zdjęcia. Najwyraźniej jednak wkraczał w Nowy Rok 1930 z niewesołym uśmiechem.

Inne portrety - pogodne zmarszczki mimiczne

Podobny wyraz twarzy o. Woronieckiego utrwalony został na fotografii, prawdopodobnie wykonanej do dowodu osobistego. Została zreprodukowana wraz z reprintem I tomu Katolickiej etyki wychowawczej i z podpisem sfotografowanego. Ojciec Woroniecki ubrany jest w ciemny strój, na szyi ma koloratkę. Ciemnopomarańczowa tonacja zdjęcia nie precyzuje barw. Przypomina, że zdjęcie jest archiwalne, zacytowane z poprzedniego wydania książki. Umieszczono je na cienkim papierze, przez który widać druk na odwrotnej stronie kartki. Charakteryzuje to działalność portretowanego: fotografia w książce, wydanej przez KUL, przypomina, że o. Jacek Woroniecki pomagał w powstaniu tej uczelni, był jej rektorem w latach 1922-1924 i wtedy napisał dla niej ten tom.

35 Por. L. Eisner, Ekran demoniczny, przeł. K. Eberhardt, Gdańsk 2011, passim oraz: Niemiecki ekspresjonizm filmowy, red. A. Helman, A. Madej, Katowice 1985, passim.

${ }^{36}$ M. Jankun-Dopart, Film kryminalny, w: Kino gatunków wczoraj i dziś, red. K. Loska, Kraków 1998, s. 104. 


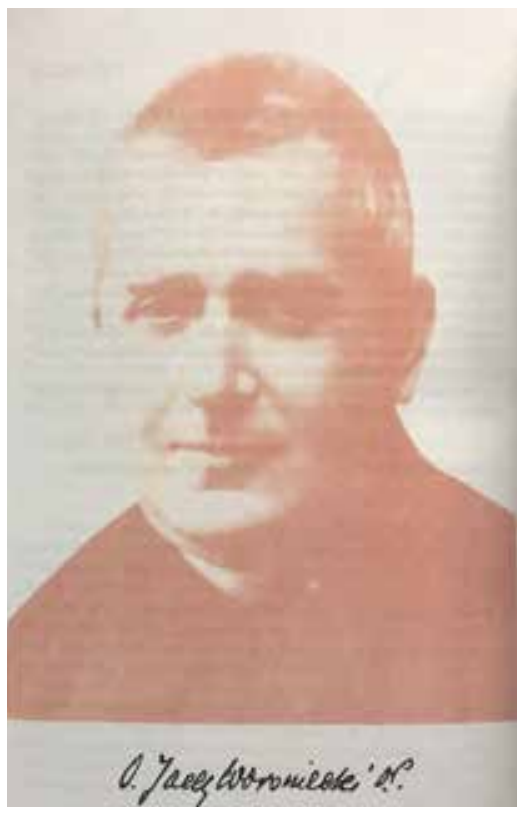

Ilustracja 8. Portret o. J. Woronieckiego zamieszczony w Katolickiej etyce wychowawczej [Źródło: J. Woroniecki op, Katolicka etyka wychowawcza, t. 1, dz. cyt., s. x]

Wykonane w ostatnich latach życia o. Woronieckiego zdjęcie również charakteryzuje go jako zaangażowanego w pracę naukową. Sfotografował go zapewne jeden z zakonników, który znał jego działalność i chciał ją zwizualizować w perspektywie jego bliskiej śmierci. Mimo zaawansowanego wieku i postępującej choroby (fotografia pochodzi z lat 1944-1946) o. Woroniecki został przedstawiony jako pochłonięty czytaniem i pisaniem. Korzysta z dużej, osobistej biblioteki. Format i oprawa trzymanej przez niego księgi wskazują, że jest to prawdopodobnie powielony maszynopis, być może nieopublikowany wtedy jeszcze trzeci tom Katolickiej etyki wychowawczej. Masywne okulary - których nie było na poprzednich zdjęciach - świadczą o kontynuowaniu pracy naukowej do ostatnich chwil życia mimo przeciążenia intensywnym czytaniem i pisaniem. Pozbawiona wyraźnego uśmiechu twarz schorowanego zakonnika jest pogodna dzięki utrwalonym wokół ust głębokim zmarszczkom mimicznym.

Wyeksponowano dominikański strój, przypominając, że o. J. Woroniecki działał na rzecz swego zakonu przekształcając go w ewangelizujący inteligencję, do której zaadresował Katolicką etykę wychowawczą. 


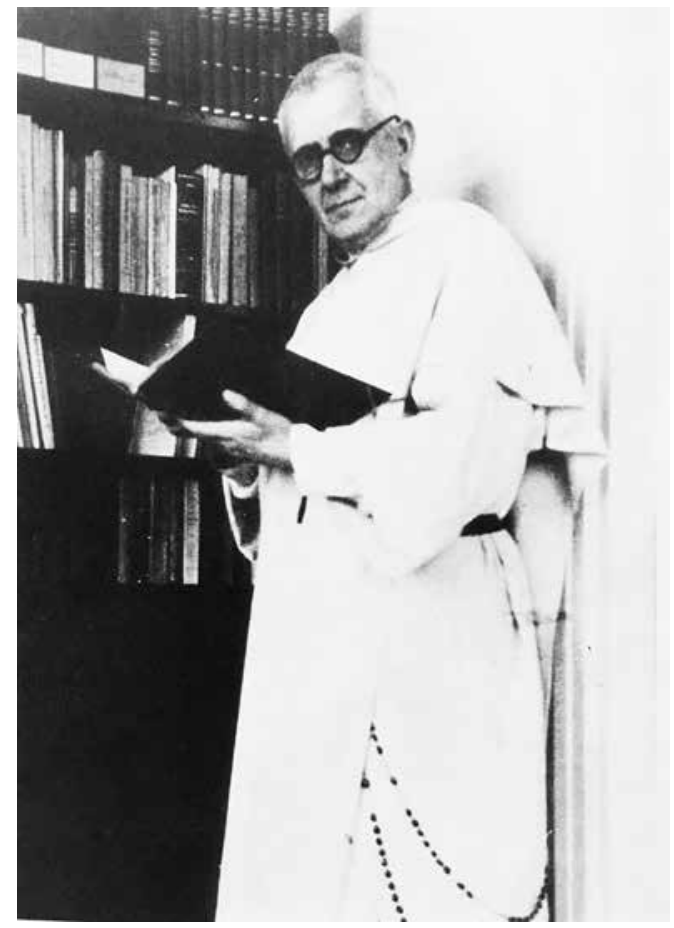

Ilustracja 9. O. Jacek Woroniecki w swej celi klasztoru krakowskiego. Archiwum Dominikanów w Krakowie. Autor fotografii nieznany [Źródło: Człowiek - moralność - wychowanie. Życie i myśl Jacka Woronieckiego oP, red. J. Gałkowski, M. L. Niedziela op, Lublin 200o, s. nlb. (ilustracja na wkładce umieszczonej na końcu książki)]

\section{Duszpasterski uśmiech}

Mimika podlega kontroli bardziej niż reszta ciała ${ }^{37}$. Można ją wypracować, a dzięki wieloletniej pracy utrwalić na twarzy w postaci zmarszczek mimicznych, wyrażających nastawienie do świata, np. optymistyczne, przekorne, pesymistyczne, tragiczne. Ekspresję mimiczną można przełożyć na słowa i odczytać przez konwencjonalne kody kulturowe ${ }^{38}$. Jest rozpoznawana intuicyjnie i wrodzona, ponieważ uśmiechają się również dzieci od urodzenia niewidome. Pozwala poznać stan psychiczny człowieka.

37 Por. Z. Nęcki, Komunikowanie interpersonalne, Wrocław 1992, s. 139.

${ }^{8}$ Por. Z. Nęcki, Komunikowanie interpersonalne, dz. cyt., s. 140. 
Ekspresja mimiczna wpływa na stan emocjonalny i samopoczucie człowieka, więc jej kontrola kształtuje słowa i czyny. Według wiersza, napisanego przez Czesława Miłosza w 1942 roku, człowiek doświadczający krańcowego cierpienia pogodnie się uśmiecha:

Rozumiesz. Jest taka cierpienia granica,

Za którą się uśmiech pogodny zaczyna ${ }^{39}$.

Oznacza to, że uśmiech może wyrażać doświadczenie i zrozumienie mechanizmów zła. Wydaje się, że tego rodzaju uśmiech dostrzegano na twarzy o. Woronieckiego. Mimo doświadczania przez niego dramatycznej historii własnego rodu i ludzkości uśmiechał się bardziej niż inni, co widać np. na fotografii ze spaceru warszawską ulicą.

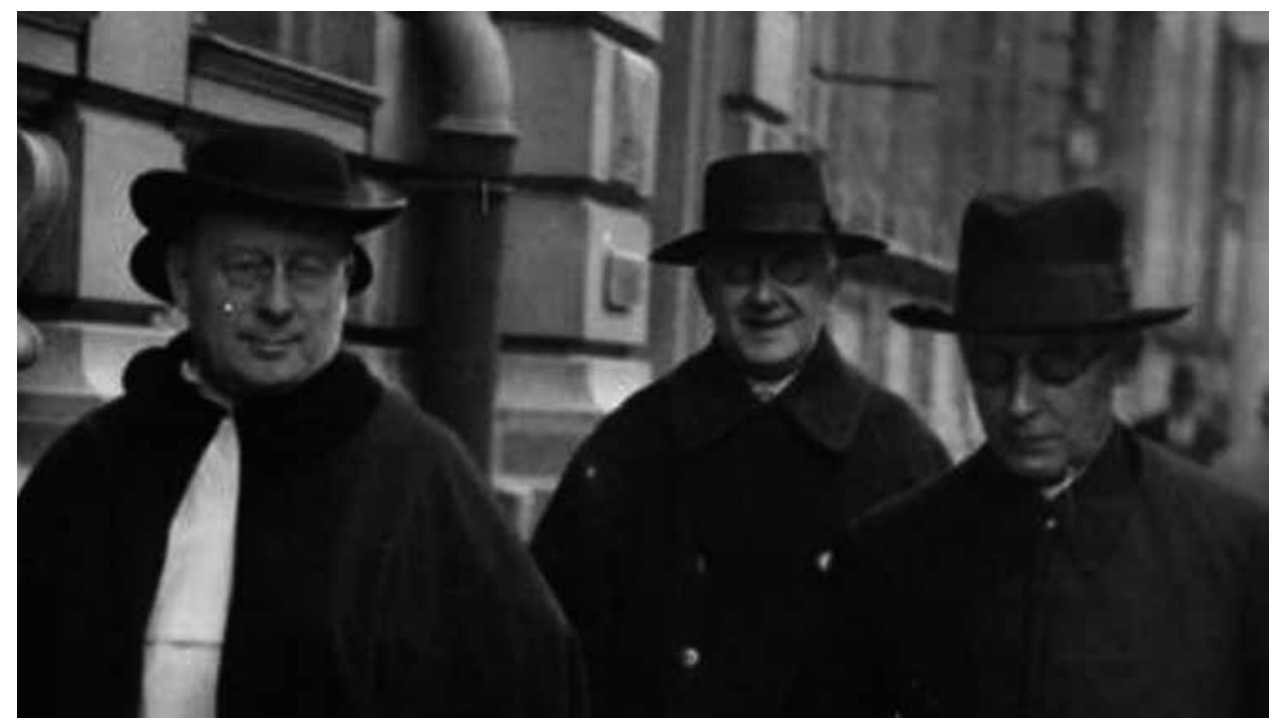

Ilustracja 10. Fragment fotografii ze spaceru o. J. Woronieckiego (na drugim planie) z generałem zakonu Marcinem Stanisławem Gilletem i Henrykiem Jakubcem po warszawskiej ulicy w 1933 roku. Autor fotografii nieznany [Źródło: Jacek Woroniecki, „Wikipedia”, https://pl.wikipedia.org/wiki/Jacek_ Woroniecki (24.10.2017)]

39 C. Miłosz, Walc (1942), w: C. Miłosz, Wiersze, Kraków 1987, s. 112. 
Wniosek: uśmiech katolickiego pedagoga

Jako katolicki pedagog o. Woroniecki ciepłym, przyjaznym „uśmiechem” demonstrował optymistyczny stosunek do przyszłości, zaufanie Bogu i wiarę w możliwość etycznego ukierunkowania polskiej inteligencji. W rzeczywistości był udręczony obserwowanymi zachowaniami i procesami oraz związaną z nimi chorobą o nerwowym podłożu. Przypominanie o Bożych przykazaniach, darach Ducha Świętego i cnotach głównych we współtworzonej przez siebie pierwszej katolickiej uczelni w Polsce uczynił remedium na moralny upadek narodu. Stał się pionierem dominikańskiego odrodzenia w wyzwolonej z zaborów Polsce.

\section{Dwa bieguny katolickiej pedagogiki: przestrogi i zachęty}

Ksiądz Ślósarz formułował przesłania w duchu tradycji i Soboru Watykańskiego i na bazie obowiązujących wówczas dokumentów kościelnych, do rodaków żyjących w zniewolonym kraju, gdy katolicyzm był kategorią wiążącą Polaków ze wszystkich zaborów. Kierował je do duchowieństwa i lokalnych katolickich wspólnot, w tym archidiecezji lwowskiej i rodaków z Węglówki, którzy żyjąc w trudnym otoczeniu kulturowym i niełatwych warunkach ekonomicznych potrzebowali jednoznacznych, dobitnych wskazówek.

Natomiast o. J. Woroniecki, działając w ramach Polskiej Prowincji Dominikanów - zakonu powołanego do zbawiania dusz na drodze contemplata aliis tradere (nauczać tego, co dała kontemplacja), formułował pedagogiczne wskazówki, opierając się głównie na Biblii, pismach św. Tomasza z Akwinu, św. Augustyna, a nawet Arystotelesa. Wskazywał wzory chrześcijańskiej doskonałości i zachęcał do ich naśladowania. Zwracał się do katolickiej inteligencji. Tłumacząc rolę świeckich w życiu Kościoła, uprzedził ustalenia Soboru Watykańskiego II.

W wychowaniu potrzebne są zarówno kary, jak i nagrody („kijek i marchewka”), toteż zarówno przestrogi ks. Ślósarza, jak i wskazówki o. Woronieckiego są wciąż potrzebne.

\section{AbSTRAKT}

Na gruncie socjologii interpretatywnej można stwierdzić, że biografie ks. dr. hab. Jana Ślósarza (1850-1917) i o. Jacka Woronieckiego (1878-1949) bardzo się różnią, ale też wykazują podobieństwa. Pierwszy pochodził z ubogiej wiejskiej rodziny, drugi był arystokratą. Żyli w czasach podobnych napięć społeczno-politycznych, wojen 
i ideologii: bolszewizmu, komunizmu, stalinizmu, nazizmu. Obaj byli związani z Lwowem i przez pewien czas trudnili się edukacją - ks. Ślósarz uczył w gimnazjach i na Uniwersytecie Lwowskim, a o. Woroniecki współzakładał Katolicki Uniwersytet Lubelski, był jego rektorem i wykładał w dominikańskich kolegiach. Ich główne książki służyły katolikom jako pedagogiczne przewodniki. Obaj formułowali w nich etyczne wskazówki, jak zachowywać się w trudnych, codziennych sytuacjach. Ksiądz Ślósarz pisał o grożących karach, odwołując się do doktryny Soboru Watykańskiego I. Natomiast o. Woroniecki pokazywał wzory i zachęcał do ich naśladowania katolicką inteligencję, uprzedzając ustalenia Soboru Watykańskiego II. W każdych czasach katolicka pedagogika - jak każda inna - wymaga zarówno odwoływania się do przestróg, jak i do stosowania zachęt.

\section{SŁOWA KLUCZOWE}

ks. Jan Ślósarz, o. Jacek Woroniecki, pedagogika, kary, zachęty, Lwów

\section{Abstract}

\section{Two Poles of Catholic Pedagogy. PhD hab. Jan Ślósarz}

\section{Priest and Father Jacek Woroniecki, O.P.}

On the basis of interpretative sociology it can be said that biographies of dr. hab. Jan Ślósarz, Catholic priest, (1850-1917) and Jacek Woroniecki, O.P., (1878-1949) differ significantly, but also show similarities. The former came from a poor peasant family while the latter one had aristocratic heritage. They lived during similar social and political tensions, world wars and criminal ideologies: Bolshwvism, Communism, Stalinism, Nazism. Both were associated with Lviv and for some time were involved in education - J. Ślósarz taught in secondary schools and at the University of Lviv, while J. Woroniecki co-founded Catholic University of Lublin (Katolicki Uniwersytet Lubelski), served as its chancellor and lectured in Dominican colleges.

The main books they written served as pedagogical guides for Catholics. Both formulated in them practical tips on how to behave in the most difficult everyday situations. J. Slósarz wrote about the threatening penalties, referring to the doctrine of the First Vatican Council. Whereas Father Woroniecki set role models and encouraged Catholic intelligentsia to imitate them, anticipating the arrangements of the Second Vatican Council. Then and now Catholic pedagogy - like any other - requires warnings and encouragement.

\section{KeYWORDS}

Jan Ślósarz priest, father Jacek Woroniecki, pedagogy, punishment, encouragement, Lviv 


\section{BIBLIOGRAFIA}

Augustynowicz A., Autoportret, http://www.kultura.malopolska.pl/record/-/record/aggregated $97051 / \mathrm{o} / \mathrm{o} / 12 / 2 / 5 / \mathrm{importDate} /$ desc?query=MEGA:\%22Augustynowicz\%20A\%22\%20AND\%2oflag:\%22hasmedia\%22?p_auth=47CvcLRs (13.08.2018).

Bardel M. ks., Z Krasnobrodu przez obozy i obczyznę do rodzinnych stron, Lublin 1994. Barthes R., Światło obrazu. Uwagi o fotografii, przeł. J. Trznadel, Warszawa 1992. в Р кеP, Patron na czasy trudne - abp Zygmunt Szczęsny Feliński, https://kosciol. wiara.pl/doc/491079.Patron-na-czasy-trudne-abp-Zygmunt-Szczesny-Felinski (15.07.2018).

Człowiek - moralność - wychowanie. Życie i myśl Jacka Woronieckiego op, red. J. Gałkowski, M. L. Niedziela op, Lublin 2000.

Czyżewski M., Socjologia interpretatywna i metoda biograficzna: przemiana funkcji, antyesencjalistyczne wątpliwości oraz sprawa krytyki, „Przegląd Socjologii Jakościowej" 9 (2013) nr 4, s. 14-27.

Eisner L., Ekran demoniczny, przeł. K. Eberhardt, Gdańsk 2011.

Jacek Woroniecki, „Wikipedia. Wolna encyklopedia”, https://pl.wikipedia.org/wiki/ Jacek_Woroniecki (24.10.2017).

Jankun-Dopart M., Film kryminalny, w: Kino gatunków wczoraj i dziś, red. K. Loska, Kraków 1998, s. 97-112.

Jastrzębski K. ks., Ks. dr Jan Ślósarz, Archiwum Parafialne w Węglówce, maszynopis; kopia artykułu: K. Jastrzębski ks., S. p. X. Dr. Jan Ślósarz, „Miesięcznik Katechetyczny i Wychowawczy" 1917 z. 12, s. 522-526.

Juszczyk S., Metoda biograficzna, w: S. Juszczyk, Badania jakościowe w naukach społecznych. Szkice metodologiczne, Katowice 2013, s. 129-134.

Keri 3539 [Ireneusz Drabik], Film nr 6: Kościół pw. Matki Boskiej Anielskiej w Węlówce, 21.02.2013, https://www.youtube.com/watch?v=pxEoFghgIL8\&t=23s (1.09.2017).

Kostkiewicz J., O potrzebie pedagogiki katolickiej jako kierunku [specjalności] edukacji uniwersyteckiej, „Pedagogika Katolicka” 2007 nr 1, s. 29-31.

Leśniak K., Dyskusje nad pojęciem i istota dokumentu fotograficznego, „Quart” 2010 nr 4 (18), s. 83-90.

Lutyński J., Metoda biograficzna i sposoby otrzymywania materiałów w badaniach socjologicznych, w: Metoda biograficzna w socjologii, red. J. Włodarek, M. Ziółkowski, Warszawa-Poznań 1990.

Mały katechizm religii rzymsko-katolickiej przełożył z niemieckiego tekstu Jan Ślósarz, Lwów 1898.

Metoda biograficzna w socjologii. Antologia tekstów, red. K. Kaźmierska, Kraków 2012. 
Meyer P., Historia sztuki europejskiej, przeł. F. Buhl, J. Ruszczyk, A. Steinborn, Warszawa 1973.

Miłosz C., Wiersze, Kraków 1987.

Nęcki Z., Komunikowanie interpersonalne, Wrocław 1992.

Niedziela M. L. op, Próba biografii Jacka Woronieckiego op i jego Wyznania, Lublin 2011. Niemiecki ekspresjonizm filmowy, red. A. Helman, A. Madej, Katowice 1985.

Olechnicki K., Antropologia obrazu. Fotografia jako metoda, przedmiot i medium nauk społecznych, Warszawa 2003.

Panofsky E., Ikonografia i ikonologia, przeł. K. Kamińska, w: E. Panofsky, Studia $z$ historii sztuki, oprac. J. Białostocki, Warszawa 1971, s. 11-31.

Pedagogika. Podręcznik akademicki, t. 1, red. Z. Kwieciński, B. Śliwerski, Warszawa 2008.

Płażewski J., Język filmu, Warszawa 1982.

Statystyka zakładu. Skład grona nauczycielskiego z końcem roku szkolnego 1894/5, w: Dwudzieste drugie sprawozdanie Dyrekcyi C. K. Wyższej Szkoły Realnej we Lwowie za rok szkolny 1895, Lwów 1895, s. 43-45, http://www.pbc.rzeszow.pl/publication/5009 (29.10.2017).

Ślósarz J. ks., Katechizm religii katolickiej dla młodzieży szkół średnich, Lwów 1897. Fragment: http://ultramontes.pl/grzechy_przeciwko_wierze.htm (19.06.2018).

Ślósarz J. ks., O cenzurach kościelnych i ekskomunikach $w$ szczególny sposób Papieżowi zastrzeżonych, Lwów 1900, http://dlibra.kul.pl/dlibra/docmetadata? $\mathrm{id}=1670 \&$ from $=$ pubindex $\&$ dirids $=42 \& \mathrm{l}=587$ (12.07.2018).

Ślósarz J. ks., O doktorach nie literatach, „Gazeta Kościelna” 24 (1917) nr 13, s. 150-151. Uziembło A., Wspomnienia lwowskie, red. D. Maciak. Z fragmentów zestawiła A. Uziembło, „Przegląd Wschodni” 8 (2001) zesz. 2 (26), s. 429-516.

Wołczański J. ks., Ślósarz Jan ks., w: Polski słownik biograficzny, t. LI / 1, zesz. 208, red. A. Romanowski, Warszawa-Kraków 2016, s. 42-43.

Woroniecki J. op, Katolicka etyka wychowawcza, t. 1: Etyka ogólna, Lublin 1995.

Woroniecki J. op, Katolicka etyka wychowawcza, t. 2: Etyka szczegółowa. Część 1, Lublin 1995.

Woroniecki J. op, Katolicka etyka wychowawcza, t. 2: Etyka szczegółowa. Część 2, Lublin 1995.

Wywiad z bratem D. Michalczewskim op, Kraków, 2.07.1998 [wywiad na temat o. J. Woronieckiego udzielony o. M. L. Niedzieli w Klasztorze oo. Dominikanów w Krakowie, spisany z nagrania przez A. Ślósarz]. 